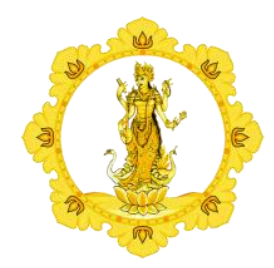

KALANGWAN

JURNAL PENDIDIKAN AGAMA, BAHASA DAN SASTRA

Vol. 11 No. 1 Maret 2021

\begin{tabular}{|l|l|l|}
\hline p-ISSN : 1979-634X & e-ISSN : 2686-0252 & http://ejournal.ihdn.ac.id/index.php/Kalangwan
\end{tabular}

\title{
ANGGAWASTA: KESADARAN JIWA DALAM KEKAWIN DHARMA NISKALA
}

\begin{abstract}
Oleh :
Ni Made Ari Dwijayanthi, S.S., M.Hum., I Kadek Widiantana, S.Pd.B., M.Pd. STAH N Mpu Kuturan Singaraja, Universitas Hindu Negeri I Gusti Bagus Sugriwa Denpasar E-mail: melodia.senja@gmail.com, kadekwidiantana@uhnsugriwa.ac.id
\end{abstract}

Diterima 09 Januari 2021, direvisi 19 Januari 2021, diterbitkan 31 Maret 2021

\begin{abstract}
Anggawasta (Author), the Universe, and the Creator are the author's methods in Kekawin Dharma Niskala to get unification with the universe through his work. Anggawasta is the term to use represent author in the Kekawin Dharma Niskala. The focus of this research is to reveal the form, function, meaning, and position of the author in text. Pierce's semiotic theory is used to interpret the signs in the kekawin.
\end{abstract}

\section{Keywords: Anggawasta, author, Kekawin Dharma Niskala.}

\section{PENDAHULUAN}

Karya sastra adalah produk olahan rasa, karenanya ia dapat memberikan rasa, dan mengangkat manusia atau pembacanya ke tingkat pengalaman keindahan dan kenikmatan tertentu (Agastia, 1994:55--56). Pengalaman-pengalaman estetik antara pengarang dan pembaca terjalin melalui komunikasi kode-kode bahasa, sastra, dan budaya. Tersublimnya rasa seorang pengarang yang kemudian menggubahnya menjadi kakawin merupakan puncak kontemplasi seorang penikmat rasa. Komunikasi pengarang dengan pembaca terjadi berabad-abad lewat interpretasi rasa seorang reseptor, yaitu pembaca.

Kekawin Dharma Niskala merupakan kekawin yang membicarakan tentang kalepasan dan kemanunggalan antara mikrokosmos dan makrokosmos. Kalepasan dijelaskan sebagai proses kesadaran antara diri (aku sebagai pengarang) dengan Semesta sebagai awal dan akhir kehidupan. Anggawasta kemudian menjadi istilah untuk menyebut pengarang yang telah mengalami penyadaran jiwa dalam Kekawin Dharma Niskala. Pengarang dalam hal ini kawi dari kekawin menunjukkan eksistensi diri mereka 
dalam teks yang kemudian teks tersebut diintepretasikan sebagai sebuah jalan kalepasan. Jalan pemujaan sederhana dengan mengarang kekawin adalah proses kesadaran jiwa yang telah mengalami pembebasan sebagai hakikat penyatuan dengan Hyang Tunggal.

\section{METODE}

Kesadaran jiwa pengarang berupa penyerahan diri secara total kepada semesta dan penguasa-Nya. Seorang pengarang hubungannya dengan semesta dan pencipta dibahas dalam penelitian ini, dengan memokuskan pada bentuk, fungsi, makna, dan kedudukan pengarang dalam kekawin. Penelitian terhadap sebuah karya sastra merupakan penelitian dalam ranah ilmu humaniora, sehingga diteliti menggunakan metode kualitatif. Selain itu metode kualitatif dapat memberikan perincian secara detail terhadap fenomena yang belum diketahui dalam objek penelitian.

\section{PEMBAHASAN}

Aku wiku ya tan hana kāku/ ikā iki ya tan hana winulatan/ wulatana ri wulatta tinon/ wěkas in wulat ika patitis (Kekawin Dharma Niskala, Bait ke-153).

Terjemahannya

Aku wiku tidak ada milikku/ ini itu tidak ada kupandang/ pandangan dilihat dalam kau memandang/ ujung pandangan, itulah arah pandangan (Kekawin Dharma Niskala, Bait ke153).

Kawi umumnya diartikan orang yang menciptakan kakawin, namun ada pula yang menyebutkan bahwa kawi merupakan sebutan bagi orang yang pekerjaannya berhubungan dengan pustaka, sastra, dan seniman. Kawi dalam Kekawin Dharma Niskala merupakan seorang kawi dan seorang wiku. Wiku sebagaimana diketahui adalah seorang pendeta pertapa. Kawi-wiku adalah seorang penyair juga seorang pertapa. Keduanya memiliki peran yang bersamaan dalam penciptaan.

Tidak semua nama kawi bisa diidentifikasi dengan dalam karya kekawin, hanya dalam Kekawin Dharma Niskala, Dharma Sunya, dan Dharma Putus, nama kawi dapat diidentifikasi. Kekawin Dharma Sunya dan Kekawin Dharma Putus menjadi dua naskah kekawin yang juga membicarakan tentang kalepasan. Masing-masing menyebut Kamalanatha sebagai kawi-wiku kekawin tersebut. Pembicaraan tentang Kamalanatha sangat jelas diceritakan dalam Kekawin Dharma Niskala dan Dharma Sunya. Kamalanatha tampak bebas menggunakan dua atribut tersebut, yaitu sebagai kawi dan wiku.

Kamalanatha seorang kawi, tidak ada satu pernyataan pun yang menyebut demikian, yang ada justru sebaliknya, yaitu sebuah pernyataan yang meniadakan "...iki tan uluh ni say kawi (ini bukan oleh seorang kawi, Kekawin Dharma Sunya, Bait ke-180)". Itu dikatakan sebagai sebuah permohonan maaf atas hasil pekerjaan yang menurut Kamalanatha sendiri tidak memperlihatkan rasa sebuah kakawin yang indah. Oleh karena itu, disarankan agar rasa itu dicari dalam persatuan niskala yang diceritakannya. Persatuan niskala atau pembebasan jiwa seperti yang telah diuraikan sebelumnya, berarti pembersihan, penyucian, dan pengosongan atau pemadaman bayu, sabda, idep. Saran Kamalanatha dapat dipahami bahwa yang disebut rasa tidak cukup dicari dengan pemahaman teks belaka, tetapi pada pelaksanaan ajaran yang disampaikannya.

Kekawin dalam hal ini khususnya Dharma Niskala, adalah suatu sarana pembersihan, penyucian, pengosongan, atau pemadaman bayu, sabda, idep. Bukan kakawin itu sendiri, melainkan pengalaman keindahan yang diadakannya. Jadi, menurut Kamalanatha, kakawin adalah salah satu manifestasi pengalaman keindahan sekaligus salah satu alat mengadakan pengalaman keindahan. Keindahan hanya mungkin dilahirkan oleh keindahan. Kamalanatha menyatakan bahwa seorang kawi menginginkan intisari pengalaman keindahan 
yaitu bebas dari keinginan. Kebebasan atau keindahan itulah pertemuan rasa. Pertemuan segala rasa dapat dipahami sebagai puncak rasa. Puncak rasa adalah persatuan niskala atau kebahagiaan yang tidak terlukiskan. Oleh karena itu, persatuan niskala disebut intisari keindahan (bdk.Palguna, 1999:176.)

Lewat pernyataan "ini bukan oleh seorang kawi", Kamalanatha justru menyatakan diri seorang kawi. Memang begitulah sepatutnya seorang kawi menyatakan diri menurut konvensi. Paling tidak ada dua cara seorang kawi menyebut dirinya. Pertama, menghindari dari penggunaan gelar tertentu bila berbicara tentang dirinya sendiri pada bagian epilog. Gelar-gelar yang dihindari antara lain kawiswara (raja kawi), kawi siddha (kawi yang telah mencapai kepenuhan), kawi nipuna (kawi mahir), karena sebutan itu biasanya digunakan untuk kawi yang menjadi pujaannya, yang mengilhaminya, pada siapa seorang kawi mempersembahkan kakawinnya. Kedua, apabila seorang kawi menyebutkan identitas kawi-nya dia akan menyatakan diri sebagai kawi yang malang, kawi tanpa karas, kawi yang belum tentu bertemu dengan keindahan, kawi yang ditinggalkan oleh kawiswara (kawi utama), dan sebagainya. Seni pengungkapan diri seperti itu kemudian disusul permohonan maaf. Ditambahkan harapan moga-moga para kawiswara mengampuni kelancangannya yang berani meniru-niru tanpa pengetahuan yang cukup. Permohonan maaf juga ditujukan ke hadapan para pembaca yang budiman dan para pandita yang bijaksana serta tidak ketinggalan para pertapa yang sakti (Zoetmulder, 1983:156-157; dalam Palguna, 1999:177.)

Permohonan maaf semacam ini telah menjadi aturan, tidak hanya dalam satu kakawin, tetapi pada setiap kekawin. Bahkan, setiap kawi menuturkan keadaan dirinya, di mana pun dalam teks, ia selalu menggunakan permohonan maaf. Sepertinya ada semangat yang melatarbelakangi adanya aturan tersebut. Semangat yang tampak di balik aturan (konvensi) permohonan maaf itu adalah perasaan kurang berarti, bahkan tidak berarti di hadapan keindahan. Kamalanatha pun ikut mengadakan aturan itu, bahkan tampak lebih ekstrem lagi karena mengatakan kakawin-nya bukan pekerjaan seorang kawi berarti "aku bukan seorang kawi". Kamalanatha tidak memakai kata-kata permohonan maaf seperti pengarang kakawin lainnya "gadung yang bergelantungan berharap mencapai rembulan", "kawi yang lupa menulis syair", atau "kawi yang ditinggalkan kawi utama." Kamalanatha justru memilih kalimat yang lugas "ini bukan oleh seorang kawi". Dengan demikian, dua cara penyebutan diri yang disebutkan Zoetmulder pada paragraf sebelumnya, sekarang bisa ditambahkan dengan satu cara lagi, yaitu seorang kawi bahkan tidak mengaku kawi. Bukan karena ia bukan kawi, melainkan betapa tidak pentingnya sebutan, identitas, nama dalam konteks pengalaman keindahan. Terlebih lagi dalam persatuan niskala (Palguna, 1999:179).

Kawi adalah orang yang dilahirkan oleh kekawin, sementara kekawin sendiri sebagaimana adanya sekarang, tidak jelas lagi diciptakan oleh siapa. Mungkin oleh seorang kawi, dua orang, atau barangkali lebih karena dalam tradisi berikutnya (sekarang) seorang kawi memiliki kewenangan, yaitu memperbaiki, menambahkan, atau menambahi sebuah kekawin. Keadaan meniadakan diri tersebut dilembagakan dalam bentuk aturan. Jadi terlalu dini menyebutkan bahwa seorang kawi memiliki tiga cara dalam penyebutan dirinya sesuai dengan suara nurani para kawi. Artinya, suara nurani kawi merupakan semangat berapi-api yang mendorong terjadinya penggubahan karya.

Memaknai aku (kawi, Anggawasta, Kamalanatha), semesta, dan Pencipta seperti melakukan rekreasi ke dalam diri. Memahami diri sebagai aku, melihat keteguhan hati seorang kawi, memandang semesta, dan terakhir merindukan Pencipta. Kerendahan hati menjadi sebuah pandangan hidup dan dasar yang utama dalam proses penyatuan. Tidak ada pemisahan antara aku, kawi, semesta, dan pencipta jika kaitannya dengan pemaknaan secara keseluruhan dalam Kekawin Dharma Niskala. Hal itu terjadi 
karena seperti yang talah dikatakan berulangulang, bahwa keseluruhan adalah proses dan jalan menuju sunyi.

Jika kemudian berbicara tentang teks dan konteks, penulis ingin memberikan penekanan pada pemaknaan bahwa kesatuan makna yang utuh terbangun atas konsistensi pengarang kekawin melakukan penggubahan dalam Kekawin Dharma Niskala. Konsistensi ini berupa wacana kalepasan di dalamnya, wacana itu sendiri menyangkut bentuk, fungsi, dan makna. Tidak ada cara yang lebih mudah meneliti dan menuliskan kalepasan dengan cara yang sederhana, mengalir, tentu dengan bingkai ilmiah sebuah penelitian.

Aku, kawi, semesta, dan Pencipta merupakan metafora yang dihadirkan kawi Kekawin Dharma Niskala untuk memudahkan pembaca memahami kalepasan. Kawi Kekawin Dharma Niskala melakukan ini karena Dia menyadari bahwa sebagai seorang Kawi, Dia tidak memiliki apa-apa, tidak juga berhak pada karyanya. Begitulah kawi Kekawin Dharma Niskala menyebut dirinya, "Aku wiku ya tan hana $k \bar{a} k u$ (Aku wiku tidak ada milikku)." Hal ini memang karena sebuah kerendahan hati, ketiadaan keinginan untuk mendapatkan apa pun.

Ketiadaan keinginan ini dikatakan sebagai bentuk sederhana kalepasan yang begitu kompleks ajarannya. Kalepasan jika dikerucutkan tidak ada ujungnya karena ujung sesungguhnya adalah ketiadaan, kekosongan, dan kehampaan. Seorang kawi menyadari hal tersebut. Oleh karena itu, sebagai sajjana (orang bijak), Dia memilih menyelamatkan dunia dengan karyanya. Karya itu sendiri adalah wujud dari kalepasan itu, seperti kutipan di bawah ini.

Swadharmma say sājjana masihin dadi/ ndatan hana tyakta ri jīwa nì sarat/ yawat ya māsih drda bhakti nityasa/ lanā nurāgeki huripnya tan běsur// (Kakawin Dharma Wimala, Wirama XIII, Bait ke-16).

Terjemahannya
Kewajiban seorang bijak adalah mengasihi (setiap orang)/ tidak ada meninggalkan jiwa (hidup) di dunia/ karena ketulusan baktinya/ kekal abadi hidupnya yang selalu mengalir// (Kakawin Dharma Wimala, Wirama XIII, Bait ke-6).

Seorang bijak juga merupakan sebutan untuk seorang kawi, hanya orang bijak yang dapat menuliskan kebajikan dan ketidakbajikan secara bersama sebagai cerminan ataupun tuntunan. Swadharmma say sājjana masihin dadi (kewajiban seorang bijak adalah mengasihi sesama). Hal itu berarti bahwa artinya setiap yang melahirkan cinta dan kasih sayang merupakan cara untuk mengobati kerinduan bertemu (baca menyatu) dengan Pencipta. Bakti yang tulus tanpa meninggalkan jejak di dunia adalah kekekalan seorang kawi karena hidup seorang kawi selalu mengalir dan menemukan muara lalu lebur menjadi satu dalam samudra kesunyian.

Seorang kawi tidak hanya menuturkan dirinya, tetapi menuturkan aku (atma) sebagai kekuatan karyanya. Aku yang bisa saja berarti dirinya (kawi) adalah bagian yang penuh romantika dalam Kekawin Dharma Niskala. Dia (kawi) seolah tidak terlibat, tetapi terlibat. Cara menyembunyikan diri di setiap kata merupakan keistimewaan yang dimiliki. Ketika karya Kekawin Dharma Niskala dibaca, pembaca (penulis) merasa menjadi aku (atma), aku (kawi), aku (semesta para kawi atau tubuh). Sungguh Kekawin Dharma Niskala penuh misteri, setiap kalimatnya adalah nyanyian sunyi yang datang dari beberapa abad silam.

Nyanyian sunyi menjadi nyanyian pengiring dalam segala kehidupan aku (atma). Rumah sunyi dapat ditemukan dengan iringan nyanyian sunyi yang konstan, terus menerus didengar, dinyanyikan, dan dilaksanakan. Suara merdu nyanyian sunyi berasal dari hati seorang sunyi.

Sāmpun labdha guru praboddha karěgěp satata lana humuygu riy hatil raksan cupwana sāri-sāri nika

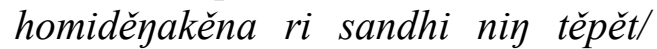


byaktāwās pahilay nikay tiga rahasya ri paměsat ikā ri niskala/nora y śabda hiděp ndatan pahaméyan pranawa huwus amindha niskala/l (Kekawin Dharma Niskala, Bait ke-7).

\section{Terjemahannya}

Sesudah berhasil ajaran (guru) yang telah bangun kesadarannya diresapi, selalu ada dalam hati/ jaga di dalam cupu hati, terus-menerus itu tujukan pada persatuan dengan benar/ terbukti jelas itu penghilang tiga yang rahasia saat sirnanya di alam niskala/ tiada kata, pikiran tidak meninggalkan bekas, aksara suci telah berpadu niskala// (Kekawin Dharma Niskala, Bait ke-7).

Kutipan di atas merupakan bait yang mengandung kata kesunyian. Kesunyian merupakan pilihan kata yang tidak terlupakan dalam tiap-tiap teks Kekawin Dharma Niskala, seolah-olah kesunyian menjadi penekanan penting kawi Kekawin Dharma Niskala. Kesunyian (sunya, putus, nirbhana), apa pun yang disebut tetaplah ia adalah kehampaan, tidak bisa dibayangkan (tan payěn-ayěn), tidak terperikan (tan patuduhan), dan di luar jangkauan pikiran (acintya). Jika digambarkan dalam bentuk tabel, maka kesunyian letaknya paling dalam. Sementara para pencari sunyi berada di sisi luar seperti molekul-molekul yang kemudian bersenyawa dengan kesunyian saat penyatuan itu telah terjadi.

Kutipan bait di atas selain sebagai bentuk konsistensi kekawin tentang kalepasan, juga mengingatkan penulis pada sebuah kejadian yang dapat dikatakan wujud sederhana aku (atma) melakukan kalepasan. Perilaku atau kejadian tanpa sadar itu adalah ketika sedang dalam keadaan penat maka mata akan terpejam sejenak, lalu ketika mata dibuka kembali, semua kepenatan sejauh mata terasa hilang. Tentu ada pertanyaan, apa penyebabnya? Semua penyebabnya adalah keinginan untuk menemukan tempat yang sunyi. Berkali-kali penulis ingin tuliskan bahwa rumah yang bernama kesunyian hanya dapat ditemukan oleh kesunyian (keheningan) pula. Kesunyian itu: Hyang Tunggal.

Seseorang yang belajar hakikat melepas tidak akan berhenti untuk senantiasa mengikhlaskan yang terjadi. Menerima sesuai dengan kadar ikhlas dalam dirinya dan berusaha mengatasi apa pun dengan memaksimalkan dirinya serta tidak mencari kambing hitam. Rasa seperti ini yang menjadi dasar dari yadnya (korban suci yang tulus ikhlas), yang pada masa sekarang sering dilakukan dengan besar-besaran, tetapi membuat pelaku yadnya menderita kemudian terlilit utang. Zoetmulder, 1991:57-58 menjelaskan, bahwa praktik-praktik matiraga berusaha memeroleh daya magis tanpa mempersembahkan korban. Sumbernya bukan lagi suatu tata upacara yang lepas dari kemauan manusia, yang dijabarkan dalam peraturan-peraturan yang baku, melainkan dalam daya upaya pribadi, perbuatan manusia itu sendiri.

Siwa yang ditujunya ada pada pusat di dalam tubuhnya, pada hulu hatinya sehingga diri menjadi tempat bernaung semesta. Cukup pujalah semua yang ada dalam diri karena di setiap tempat tubuh manusia adalah tempat para dewa. Segala sesuatu (dalam tubuhmu) merupakan hidup yang keramat (Sanghyang Hurip), merupakan Ciptaan Tertinggi (Wisesa-Karya), tubuhmu: dalam tangan, dalam kaki, kulit, daging, otot, tulang, pembuluh utama, buah pelir, jantung, empedu, pangkal tenggorokan (Soebadio, 1985:111). Setiap titik pada tubuh adalah aksara yang hidup dan selalu bergerak ke segala penjuru menghidupkan sudut-sudut pikiran. Bukankah tubuh dikatakan Bhuwana Alit yang merupakan bentuk analog dari Bhuwana Agung. Tubuh sebagai lautan luas yang penuh gejolak, tetapi semakin diselami jauh ke dalam, ketenangan akan didapati. Lautan yang tenang adalah tempat segalanya bermula dan bermuara. Demikian pula tubuh yang selalu membebaskan diri untuk menjadi apa pun.

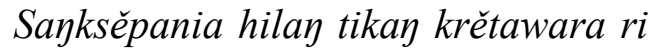
sira wuwus atingal ing kriya/ ya deniך 
ya tatan hana guru kasisya ri sira natimuddha nirguna/ ngka teygwan katěmu $\eta$ rasa ta ya warah kadi

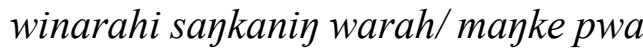
katěkan wěkasnin amiweka ri hilayanikay tutur hiděp// (Kekawin Dharma Putus, Wirama I, Bait Ke-4).

\section{Terjemahannya}

Pendeknya, tiada anugerah dari beliau yang telah meninggalkan upacara religi/ makanya adalah tidak ada guru tidak ada murid, bagi beliau tidak ada kebodohan, tidak ada kekurangan/ itulah tempat pertemuan perasaan yang disadari bagaikan diberi tahu oleh sabda Ilahi/ kini hingga di kemudian hari manakala memperlakukan dengan hati-hati hilangnya kesadaran batin// (Kekawin Dharma Putus, Wirama I, Bait ke-4).

Sesungguhnya sesuatu yang dicari ke luar akan ditemukan dan hilang di dalam diri. Tidak ada yang lebih bodoh atau lebih pandai, tidak ada guru pun tidak ada murid. Semua sama, lahir dari kekosongan berakhir dengan kehampaan. Tubuh aku (atma, penyair) adalah kumpulan rasa yang dipertemukan oleh keinginan penyaatuan. Kerinduan pemujaan sama dengan keperihan yang indah. Bukankah, semua bermula dari dalam diri, maka tetaplah kembali ke dalam diri.

Diri merupakan kuil pemujaan, "alam olah tapa-brata itu konsentrasi batin merupakan salah satu praktik yang paling penting sehingga lambat laun "diri pribadi" atau Atman makin diutarakan. Dalam lingkungan kehidupan pribadi sang Atmanlah menjadi pusat yang memancarkan segala daya kekuatan, sama seperti Brahman yang menjadi pusat semesta" (Zoetmulder, 1991:58). Paramasiwa yang dituju ada pada pusat di dalam tubuh, pada hulu hati sehingga diri menjadi tempat bernaung semesta.

Cukup pujalah semua yang ada dalam diri karena di setiap tempat tubuh manusia adalah tempat para dewa. "Segala sesuatu (dalam tubuhmu) merupakan hidup yang keramat (Sang Hyang Hurip), merupakan Ciptaan Tertinggi (Wisesa-Karya), tubuhmu: dalam tangan, dalam kaki, kulit, daging, otot, tulang, pembuluh utama, buah pelir, jantung, empedu, pangkal tenggorokan" (Soebadio, 1985:111). Oleh karena itu, setiap titik pada tubuh adalah aksara yang hidup dan selalu bergerak ke segala penjuru menghidupkan sudut-sudut pikiran.

Bait ke-4 dari Kekawin Dharma Putus yang telah dikutip di awal subbab di atas mewakili kesederhanaan jalan kalepasan. Kesederhanaan yang dimaksudkan bukanlah tanpa usaha, melainkan tanpa upacara. Justru ritual yang terpenting adalah ritual perkumpulan rasa (ngka teygwan katěmu $\eta$ rasa ta ya warah kadi winarahi saykaniy warah/ itulah tempat pertemuan perasaan yang disadari bagaikan diberi tahu oleh sabda Ilahi). Tubuh adalah tempat pertemuan rasa, setiap rasa berkumpul di hulu hati. Pusat yang dikatakan menjadi bagian tengah-tengah tubuh, baik secara vertikal maupun horizontal ialah hulu hati.

Soebadio, 1985:45--48, menjelaskan aksara-aksara yang dimiliki di setiap titik pada tubuh akan hidup dan berputar di dalam hulu hati. Setiap aksara yang terdiri atas sepuluh aksara (SA, BA, TA, A, I, NA, MA, SI, WA, YA disebut dasaksara), kemudian menjadi lima aksara (SA, BA, TA, A, I disebut pancaksara), lalu menjadi tiga aksara (ANG, UNG, MANG disebut tryaksara), dan terakhir menjadi (OM disebut ekaksara). Ekaksara menyuarakan OM dengan sebutan ongkara. Penghuni hulu hati adalah ongkara ngadeg dan ongkara nyungsang. Keduanya perwujudan lingga-yoni yang mewakili karakter maskulin dan feminis dalam diri. Jika ongkara ini diputar, maka timbullah getaran yang menciptakan kehangatan, kenikmatan, dan kebahagiaan yang luar biasa.

Analog tubuh dengan semesta beserta para dewa yang bersemayam dipaparkan dalam Kidung Ajikembang (bait 1-10). Dikatakan bahwa sinar suci Sanghyang Widhi dalam wujud sembilan dewa, menghuni kesembilan penjuru alam semesta dan organ vital dalam tubuh manusia dalam rangka memberikan kekuatan dan perlindungan demi 
kesempurnaan hidup manusia. Kesembilan dewa penguasa tubuh dan semesta disebut dengan dewata nawa sanga, terdiri atas Dewa Iswara, Dewa Maheswara, Dewa Brahma, Dewa Rudra, Dewa Mahadewa, Dewa Sangkara, Dewa Wisnu, Dewa Sambu, dan Dewa Siwa (Suarka, 2007:157).

Suarka, 2007:157 menegaskan, bahwa di alam semesta, Dewa Iswara berada di alam timur. Di dalam tubuh (manusia), Dewa Iswara bersemayam di jantung bertugas memberikan keselamatan dan perlindungan, kekayaan, serta menumbuhkan rasa bakti kepada Tuhan. Dewa Maheswara berada di alam tenggara. Di dalam tubuh manusia, Dewa Maheswara bersemayam di paru-paru, memberikan kepandaian sehingga manusia mahir dalam kehidupan. Dewa Brahma berada di alam selatan, bersemayam di hati, memberikan kekuatan dan perlindungan sehingga manusia menjadi sempurna, panjang umur, dan mampu menguasai pengetahuan suci. Dewa Rudra berada di alam barat daya, bersemayam di usus, memberikan kesadaran akan kebenaran, mendidik manusia berperilaku baik, dan menjadi teladan di muka bumi.

Dewa Mahadewa berada di alam barat. Di dalam tubuh, Dewa Mahadewa bersemayam di ginjal, memberikan kekuatan dan perlindungan kepada manusia serta menumbuhkan sifat dan sikap keberanian pada diri manusia. Dewa Sangkara bersemayam di alam barat laut, dalam tubuh bersemayam di limpa, memberikan kekuatan dan perlindungan kepada manusia dalam mengendalikan diri dan memiliki kesetiaan. Dewa Wisnu menguasai alam utara, bersemayam di empedu, memberikan kekuatan dan perlindungan sehingga manusia memiliki keteguhan hati, sopan dalam bertingkah laku, bijaksana, dan rupawan. Dewa Sambu berada di timur laut, bersemayam di katup jantung, memberikan kekuatan dan perlindungan serta menumbuhkan rasa kedamaian dan cinta kasih pada diri manusia. Dewa Siwa berada di alam tengah, bersemayam dalam tumpukan hati, memberikan kekuatan dan perlindungan serta menumbuhkan kewibawaan, tingkah laku luhur, kesetiaan, kejujuran, dan kegemaran untuk melakukan semadi pada diri manusia (Suarka, 2007:157).

Kekuatan para dewa dalam tubuh manusia beserta aksara-aksaranya juga terdapat dalam Jnanasiddhanta. Seperti yang sudah dijelaskan pada latar belakang bahwasanya kalepasan dalam KPD tidak didapatkan hanya dengan membaca KPD, tetapi harus dibekali pengetahuan lain tentang teks-teks lain dengan ajaran yang sama. Berikut ini merupakan tabel dasabayu yang dibentuk dari pemahaman dasaprana dan dasa-atma (Soebadio, 1985:26--27).

Niskala-sunya-putus, tidak dibedakan begitu mencolok dalam isinya, tetapi ketiganya memiliki hubungan yang tidak terpisahkan sebagai ajaran kalepasan tingkat lanjut (niskala). Misalnya kutipan dalam Jñānasiddhanta di bawah ini yang mengatakan, bahwa kalepasan merupakan jalan yang dipilih untuk pembebasan jiwa, serta tempat di tubuh yang dipilih untuk pembebasan.

Om namah siwāya

Ikay pinaka mārga nì kapralinan de say pandita tiga lwirnya

Nistha : riy Siwa-dwara

Madhya : riy tütuy in ghrana

Uttama: rig tutuk

Ika ta katiga nora mulih riy janma muwah, yan kěna karěgépan in Niskala-Jñāna. Nkāna sinayguh Parama-Kaiwalya, liy say pandita.

Sira Acintya-pada. Acintya ya, tan

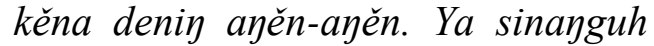
Acintya-pada sira. Ya ta matayhyan tutuh in payawruh say bhujayga. Ika riy kina-kina, ri say Siwa-Buddha. Maykana tan hana waněh kumawruhi lawan ta say bhujayga, tan kagawokana riy payawruh in apayawruh; ayhiy Siwa-Buddha juga, ya tutèn payawruhira. Apan ta sira aywruhi kinaruhan, hinan igahisi lawan tan pesi (Soebadio, 1985:92). 
Terjemahannya

\section{Om Hormat kepada Siwa}

Adapun tiga jalan bagi sang bijak yang menuju peleburan:

(jalan lewat) upacara nistha ubun.

: (jiwa ke luar) lewat ubun-

(jalan lewat) upacara madhya(ma)

: (jiwa ke luar) lewat ujung

hidung.

(jalan lewat) upacara uttama

: (jiwa ke luar) lewat mulut.

Ketiga (jalan) ini semuanya tidak menuju kelahiran kembali lagi, asal seseorang telah menguasai pengetahuan mengenai Dunia yang tidak tampak (Niskala-Jñāna). Di sana terdapat Kesunyian Tertinggi (Parama-Kaiwalya), menurut sang bijak.

Di sana terdapatlah Takhta Acintya (Acintya-pada). Acintya berarti tidak dapat ditangkap oleh akal budi atau pikiran. Itu disebut Acintya-pada, tempat bagi Dia yang tidak terkurung oleh konsep-konsep. Itulah puncak pengetahuan bagi seorang murid. Sejak zaman dahulu tempat ini diketahui oleh pendeta-pendeta Siwa dan Buddha. Dengan demikian, tidak seorang pun tahu, kecuali orang-orang bijak, tidak seorang pun pantas dikagumi karena mengetahui mereka yang mempunyai pengetahuan, hanya pemuja-pemuja Siwa dan Buddha, merekalah hendaknya diikuti dalam pengetahuan mereka. Karena mereka tahu, apa yang (pantas) diketahui termasuk yang ada isinya dan yang tidak ada isinya (Soebadio, 1985:93).

Sejatinya jalan yang dimaksudkan itu merupakan jalan yang ada di dalam tubuh. Pengetahuan dan ajaran berperan sangat penting dalam pembentukan kekuatan jiwa atau keteguhan hati pencari sunyi. Memang ajaran kalepasan sangat bersifat rahasia karena pengetahuan tingkat tinggi ini hanya bisa diterima dan dijalani oleh seseorang yang bijak. Kecerdasan, intelektual bukanlah ukuran yang menjadi dasar seseorang memiliki sikap bijak. Justru sikap bijak hanya dimiliki oleh seseorang yang sederhana, penuh penerimaan, dan selalu berusaha menggapai tujuan yang kosong.

Tiga jalan di atas terkadang lebih dikenal dengan tiga jalan kematian. Jalan kematian tersebut dipahami sebagai jalan pembebasan total. Pembebasan total diartikan sebagai menyatunya aku (atma) dengan Pencipta, bukan sebagai pertemuan dengan yang menjadi dewa-dewa yang diharapkan hadir pada saat pemujaan. Pembebasan total adalah cara membimbing jiwa yang sedang berangkat menuju ke kesunyian.

Pemusatan pikiran merupakan cara sederhana yang dikatakan oleh seorang bijak. Pembebasan jiwa ini tentu tidak mengharapkan keinginan mendapatkan imbalan, pembebasan jiwa adalah jalan untuk memutus reinkarnasi. Seseorang yang dikatakan telah mencapai titik sunyi tidak akan bisa kembali untuk bereinkarnasi ke alam sakala.

Seorang pencari sunyi tidak hanya dinilai dan ditentukan oleh fisik semata, terkadang banyak yang berpura-pura sebagai pencari sunyi. Mereka yang berpura-pura kadang tidak menyadarinya. Kepura-puraan justru disebabkan oleh ingin menunjukkan diri, seolah paling sunyi, paling tahu segalanya, termasuk paling tahu tentang sastra. Kepura-puraan ini cenderung akan mengakibatkan penderitaan terlebih lagi tidak akan mampu mencapai pembebasan total tersebut.

\section{SIMPULAN}

Karya sastra adalah produk olahan rasa, karenanya ia dapat memberikan rasa, dan mengangkat manusia atau pembacanya ke tingkat pengalaman keindahan dan kenikmatan tertentu. Sastra adalah sikap, sastra bukanlah jalan yang dilakoni untuk mencapai sebuah ketenaran. Sastra lebih 
kepada ajaran menjadi seorang yang sederhana, anggawasta. Kesopanan, dinilai bukan dari luar (orang lain), melainkan dari diri sendiri dengan becermin pada sikap orang lain. Sikap atau perilaku seseorang dapat dilihat dari seberapa jauh mereka memahami dan mengamalkan sastra dalam hidupnya karena hidup adalah sastra dan sastra adalah sikap. Memaknai aku (kawi), semesta, dan Pencipta seperti melakukan rekreasi ke dalam diri. Memahami diri sebagai aku, melihat keteguhan hati seorang kawi, memandang semesta, dan terakhir merindukan Pencipta. Kerendahan hati menjadi sebuah pandangan hidup dan dasar yang utama dalam proses penyatuan. Tidak ada pemisahan antara aku, kawi, semesta, dan pencipta jika kaitannya dengan pemaknaan secara keseluruhan dalam Kekawin Dharma Niskala. Hal itu terjadi karena seperti yang talah dikatakan berulangulang, bahwa keseluruhan adalah proses dan jalan menuju sunyi.

DAFTAR PUSTAKA

Agastia, Ida Bagus Gede. 1999. Di Kaki Pulau Bali. Denpasar: Yayasan Dharma Sastra.
2010. Yoga Sastra. Denpasar: Yayasan Dharma Sastra.

Creese, Helen. 2012. Perempuan dalam Dunia Kakawin; Perkawinan dan Seksualitas di Istana Indic Jawa dan Bali. Denpasar: Pustaka Larasan.

Palguna, IBM Dharma. 1999. Dharma Sunya Memuja dan Meneliti Siwa. Denpasar: Yayasan Dharma Sastra.

Ratna, Nyoman Kutha. 2007. Teori, Metode, dan Teknik Penelitian Sastra dari Strukturalisme hingga Poststrukturalisme Perspektif Wacana Sastra. Yogyakarta: Pustaka Pelajar.

Soebadio, Haryati. 1985. Jnanassiddhanta. Jakarta: Djambatan.

Suarka, I Nyoman. 2007. Kidung Tantri Pisacarana. Denpasar: Pustaka Larasan.

Yasa, I Wayan Suka. 2007. Teori Rasa: Memahami Taksu, Ekspresi, dan Metodenya. Denpasar: Widya Dharma.

Zoetmulder, P.J. 1994. Kalangwan Sastra Jawa Kuno Selayang Pandang (cetakan ketiga). Penerjemah Dick Hartoko SJ. Jakarta: Djambatan. 